\title{
The present situation analysis of human resources in university library in China
}

\author{
Na Lin', a \\ ${ }^{1}$ Jilin Agricultural University, Changchun, Jilin province, China \\ a36670921@qq.com
}

Keywords: Library cause, the university library, human resources, analysis of the situation

\begin{abstract}
This article through to a university library human resources management, gathered a large number of detailed data, mainly from the perspective of the human resources management innovation, the actuality of the university library human resources management, and cannot adapt to the development trend of university library's problem, and explains the connotation of humanistic management and library's humanistic management and service principle, to explore humanistic strategies of internal management and reader service of library.
\end{abstract}

\section{Introduction}

Human resources construction is related to the survival and development of the library, "in the world today any library should maintain its survival and development, must depend on three resources: one is the hardware resources, including the library, books, equipment; second, financial resources, i.e. funds; third, human resources, librarians and its potential human", the wide coverage of human resources, the most dynamic, it can control the other two resources usage [1]. To be said in the library, in the role of library services, library buildings account for 5\%, information resources (20\%), and librarians accounted for $75 \%$. Human resource effectiveness play the most flexible, most has the vigor, it is a variable, if the inappropriate or mismanagement, even with a rich collection and ample funds, also it is difficult to play their role [1]. Thus, human resource construction of library, attach importance to talents, training talents, improve the overall quality of library staff, on-the-job training and implementation of all members of the library are constantly to continue education, related to the existence and development of the library event.

\section{University library human resources management present situation and existing problems}

Post Settings and functions of the library, the library at present does not adapt, talent use does not match with the library post setting, personnel training and library work task does not adapt, incentives and librarians' job performance does not adapt the phenomenon such as still can't adapt to the development trends of JT university library, human resources management mainly exist the following problems.

Backward management concept. Due to the weak consciousness of human resource management, the human resources management still stays in the personnel management phase, not as people can develop and value-added resources to use and investment [2]. The management of the library, in a long time, mainly adopts heavy and weight system management method, with literature as the center, to work as the center, library work just borrow some is also the mind-set of entrenched. Management emphasizes the organization division of labor, hierarchical, few managers, most of the librarians is negative to execute commands, have no voice in the library management, no self control to the labor of duty, enthusiasm and creativity of the librarians of not play [2]. Although later in the democratic management, target management, new management methods such as the rationalization proposal, but I haven't reached the idea of humanistic management level.

The structure of talents is not reasonable. The library needs certain talent resources to support, but the rationality of the evaluation library to use human resources, can't see the total number of highly educated, high professional titles and proportion, and to consider reasonable structure of talent from the library [3]. Some libraries lack of long-term planning of talent resource configuration, 
regardless of the actual need, ignore the level of library work, does not take into account the structure of talent, talent structure random due to the change, restricted the library construction and development. JT university library statistics show that in 2010:

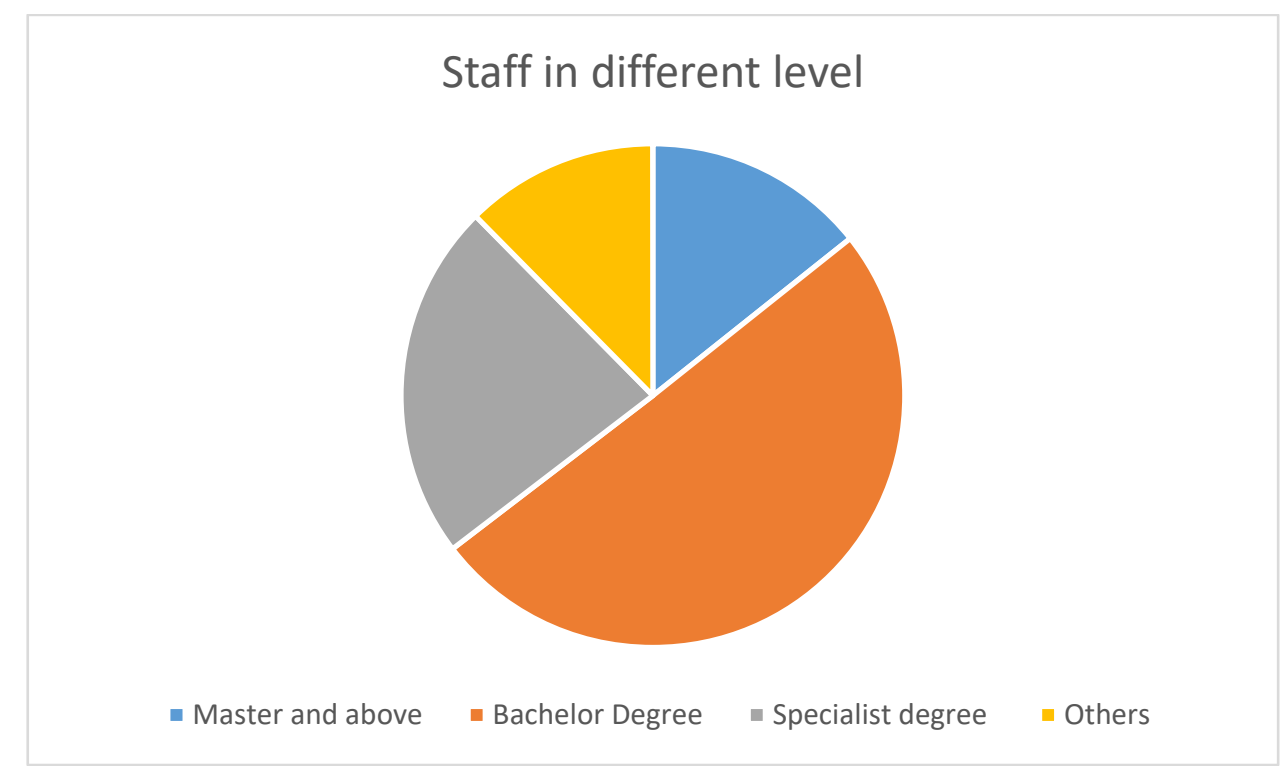

Fig. 1 Different level of JT university library

The library on a total of 161 employees. Of which 39 people, senior titles accounted for $24.2 \%$ of China, the total number of; Intermediate title 81 people, accounting for $50.3 \%$; Primary title 20 people, accounting for $8.1 \%$. Professional technical team structure proportion, senior professional titles accounts for only $24.2 \%$, especially senior is too little.

Degree structure

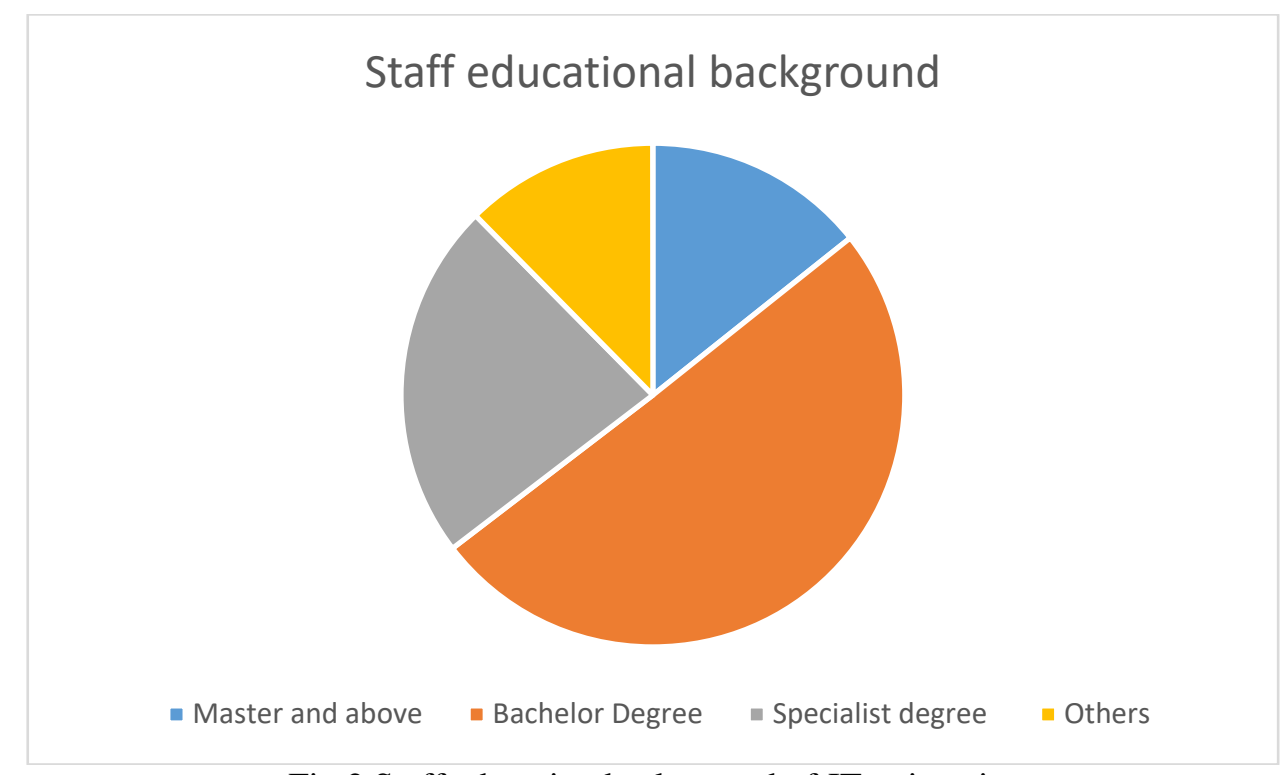

Fig.2 Staff education background of JT university

Currently has a master's or higher degree in 23 (not including reading master's 16 people), accounted for $14.3 \%$ of China, the total number of; Undergraduate 81 people, accounting for $50.3 \%$; Specialized subject 37 people, accounting for $23 \%$. Has a master's degree in professional and technical personnel is much lower than the proportion of foreign university library, the proportion of $30 \%$ to $50 \%$.

Post setting is not reasonable. Because of the influence of long-term planned economy system, when a professional jobs, or continue to use the practice of planned economy, there are positioned, 
and by hiring phenomenon. All with the goal of "make, men", make the real suitable for certain jobs, having the ability of the business people not be reused, and are in urgent need of talented person's post cannot get the required talent, talent and serious out of jobs [3]. Library reform, at present is mainly on the human resources management reform, namely staff positions, job performance, job performance, task completion are linked to personal status and income. In the reform process, the key is to admit, the departments and job, the reality of the difference between the individual and individual, and divided into various differential factors scientifically, through reasonable differential zoom in and out, to set up posts scientifically, reasonably for finding and is looking for work, reasonably determine the differential treatment of different position, so as to improve the efficiency of management, improve the quality of each department and each post work.

With severe shortages of interdisciplinary talents with high quality. Library work in the 21st century require staff must have a high professional level, the skillful operation of a computer skills and master a foreign language, and other related disciplines of knowledge, it is base point with between the master of professional, seeking more tentacles interdisciplinary talents development, is the need of the development of today's knowledge economy era the library cause [3]. Present library staff and it is difficult to meet the requirements, they are still in a single operational state, the competitive consciousness is not strong, weak efficiency concept, business ability is weak, the management level is low, and the knowledge economy condition in the construction of library business new problems and new situations to distinguish ability is poor, weak strain capacity.

\section{University library human resources management is perfect}

For library information resources is the source of its survival, but at the same time, human resources and it is an important basis of access to information resources. Therefore, how to strengthen the library human resources development and management, make good use of human resources, improve the work efficiency, to inspire the tremendous potential, realize the goal of the library in the future, the development and expansion of the library, and plays a vital role.

The library management and service of humanistic principles. The library work is collecting, processing and finishing, development, and to provide the literature information resource service, its all management activities depend on the librarians, reader's service. The reality of the work in the library, "people-oriented" is mainly manifested in two aspects: one is "based on readers", equally to readers, literature convenient layout, service environment clean, elegant, quiet, enthusiastic service attitude, service efficiency, fast, let the reader feel pleasure in the process of using the library; The second is "based on librarians in the internal management, to librarians practice humanistic management, people have respect, equality, care, development, such as psychological needs, to meet these requirements of librarians is the embodiment of the humanistic management [4]. To respect librarian, arouse their working initiative, initiative, creativity, excavate its potential, in order to better service for readers. In the university library management, adhere to the principle of humanism, is to do a good job of modern university library management the fundamental guarantee.

Establish an effective management mechanism. In order to adapt to era development, library should break equalitarianism, through pressure mechanism, competition mechanism, incentive mechanism, etc., resulting in the specification, the behavior of the librarians through material rewards and spirit award arouse the enthusiasm of the librarians' study, work, stimulate their subjective initiative, constantly innovate in the work. University library should be based on the rule of its work and the need of the various aspects to create positions, complement, set tasks, rewards and punishments, sign post responsibility system, realize the goal of effective management [4]. Develop modern management innovation award and reward system to mobilize enthusiasm and creativity of each librarian.

Optimizing the allocation of human resources. Library work multifarious, all jobs have different requirements, the library leaders to restraining, based on the characteristics of each of the librarians, the librarian's career with the library undertaking development [5]. Through to the librarian's personality, ability, status quo and so on carries on the careful observation and comprehensive analysis, according to the need and the librarian's personality, ability to work, director 
of choose and employ persons, avoid people short, achieve the best combination of human resources. To the rational use of human resources of university library, scientific arrangement positions, reasonable configuration management of department librarians, computer equipment maintenance librarians, business process management (BPM) librarians, information retrieval, multimedia information management librarians, etc., to let them in the suitable for their own interests, the ability to post to give full play to their potential. If every librarian in its work creatively in light of the right post, it's potential into full play, so, the level of the management and service of university library and level will rise to a new height.

Establishing incentive mechanism is beneficial to the development of librarians. Incentive is the core of humanistic management, it is in the important position in modern library management. In order to mobilize the enthusiasm of the librarians, it is necessary to establish scientific and effective incentive mechanism, continuously meet the diverse needs of librarians [5]. Leadership must be good at in university library, according to different situations and different people take the goal motivation, spiritual motivation, competition motivation, reward motivation and other targeted incentives, to encourage all the staff work hard, positive and uplifting, inspire staff enthusiasm, initiative and creativity, librarians based on jobs to make great contributions to the library at the same time, their own life value and social value is realized. The incentive way to note that a librarian to personal development and the development of library cause to unify; Second, we must combine material incentive and spiritual incentive.

To establish effective communication mechanisms and to develop team spirit. Library work as a whole, between the librarians and organic connection exists between the various business departments. Leadership must be good at using emotional management of university library, often communicate with staff, to achieve mutual understanding and support [5]. To take effective working method, more care, respect, care for the treatment of life, spiritual life and mental health, etc., in the museum build a trust each other, care about each other, support each other, help each other good human environment, to form a unity, cooperation and coordination of the team, the potential of the librarians in all valued, all good atmosphere into full play, and respected your best to do well the work of university library.

\section{The strategy of human resources of library}

Strengthening the concept of "based on readers" service. Thought is the forerunner of action, the library only to the service principle of "based on readers" rooted in the heart of a librarian, can we truly achieve the "reader first and service first" [6]. Library leaders should, therefore, through various forms of education activities, strengthening the librarian "based on readers" service concept, and from all aspects of the library work to practice this concept, let all readers (including from network access to the pavilion and the library reader) the status of the respected, rights and interests maintenance, needed to get the high quality service.

Environmental design humanization. Change the pattern of the traditional library to library as the center, in the aspect of layout, the external environment of the build to the reader as the center, in order to make it easier for readers to use the literature information and exchange activities for the premise, to create a comfortable, beautiful environment. Change the traditional Tibetan, borrow, independent reading way of management, the Tibetan, borrow and read integration management mode, on the one hand, can maximum limit satisfy the demand of readers, improve the utilization rate of literature information, on the other hand can also reduce the labor intensity of librarians [6].

To form a flexible and efficient organization. Editorial, circulation and reading of library traditional functions, such as the business mutually exchanges, as a result causes of library literature information resource construction and disjunction of library literature information service, has not adapt to the information network times reader demand and resource diversification literature information service requirements [6]. To change this pattern, it must be in the library organization restructuring according to function, form the literature information resources, in charge of China, all the Tibetan literature information acquisition and processing; Formation of documentary information 
service, and is responsible for the collection of literature reading and circulation; Establish information service department, responsible for all

\section{Summary}

University library is the information service center for teaching and scientific research in colleges and universities, the knowledge economy era of the university library is facing unprecedented challenges, the development trend of university library in the 21st century, human resources will become the library survival and the main factors of sustainable development, only full attention "people" in the library activities and strengthen the human resources development and management of the library, to people-oriented concept innovation of library service and management, to improve work efficiency, and realize the goal of library development, library undertakings have developed fast and lasting.

\section{References}

[1] H.M. Shen. Incentive under the perspective of university library human resource management, Journal of xi 'an institute of Eurasia Journal, 2009, vol.5, pp. 69-71.

[2] R.P. Li, Under the network environment library human resource management, Journal of Jiamusi University of social sciences, 2010, vol.24, pp. 176-177.

[3] J.Y. Pan, On building incentive mechanism in the library management paradigm, Books intelligence work, 2009, pp.56-59.

[4] J.L. Wu, "Effect" theory in the use for reference in library human resource management, Science and technology intelligence development and economy, 2009, vol.6, pp.32-37.

[5] Y.M. Gao. Expectancy theory in library human resource management, Human resource management, 2007, vol.2, pp.6-11.

[6] J.H. Lu, University research library service innovation system. Mechanical Management and Development, 2004, pp.10-15. 